\title{
EGYÉNI TELJESÍTMÉNYÉRTÉKELÉS A MAGYAR KÖZIGAZGATÁSBAN EGY FUNKCIONÁLIS ELEMZÉS
}

A szerzố dolgozatában az egyéni teljesítményértékelést (ETÉ) és az ahhoz kapcsolódó béreltérítés funkcionális elemzését kísérelte meg elvégezni a rendelkezésre álló több kérdő́ives adatfelvétel során szerzett adatok alapján. A kérdés: betölti-e funkcióját az egyéni teljesítményértékelés, azaz a kapott adatok arra utalnak-e, hogy hatékonyabb teljesítményösztönzés és motiválás valósul-e meg a közigazgatásban?

Kulcsszavak: egyéni teljesítményértékelés (ETÉ), közigazgatás, köztisztviselók, Magyarország

A dolgozók teljesítményének rendszeres értékelése talán valamennyi modern szervezetben jelentkező feladat. Sajátosan jelentkezik ez a feladat a közigazgatásban, amelyben különösen jellemzố a formalizáltság. Az emberieróforrás-menedzsmentet általában, $\mathrm{s}$ azon belül a teljesítményértékelést is számos, tipikusan jogszabályi formában megjelenő általános előírás szabályozza.

A magyar közigazgatásban az egyéni teljesítményértékelést (ETÉ), illetve ahhoz kapcsolódóan a bér eltérítésének (béreltérítés) lehetőségét a közszolgálati törvénynek (1992. évi XXIII tv. - KTV) egy 2001-ben hatályba lépett módosítása vezette be. A bevezetést legjobb tudomásunk szerint nem elôzte meg az érintettek felkészítése; nem történt meg a mintegy 12.000 közigazgatási vezető ilyen jellegú képzése, illetve az esetleges költségvetési kihatások áttekintése sem. Bár a módosítás indoklása nemzetközi tapasztalatokra hivatkozik, nem ismerünk olyan rendszert, amely a közigazgatás teljes személyi állományát ilyen jellegú ETÉnek vetné alá; az ETÉ tipikusan vezetốkre vonatkozik. A legtöbb szerző egyetért abban is, hogy a teljesítményértékelés bevezetett módja teljességgel idegen a magyar közigazgatás múködési logikájától és személyzeti rendszerétól (Hajnal, 2007; Linder, 2006; Gajduschek, 2007). E tényt jól mutatja, hogy jelenleg egyszerre két, céljaiban és eszközeiben gyökeresen eltérő, inkompatibilis értékelési módszert is „,múködtet” a hazai szabályozás: az ETÉ mellett továbbra is él a minősítés rendszere (Gajduschek, 2004; 2007). Jelenleg folyamatban van az ETÉ egy teljesen új rendszerének bevezetése, miközben a döntéshozók tervezik egy harmadik fajta értékelési rendszer, a kompetenciaelemzés és -értékelés bevezetését is. Ily módon a magyar közigazgatás, a világon talán elsőként, múködtethetne egyszerre három értékelési rendszert. ${ }^{1}$

Az utóbbi idóben több olyan elemzés is napvilágot látott, amely empirikus adatok segítségével próbálja meg bemutatni a teljesítményértékelés hazai gyakorlatát, illetve megkísérli az általánosabb összefüggéseket feltárni. Linder (2006) - az ETÉ mellett a kompetenciaelemzés és -értékelés módszerét is vizsgálva - a hazai megoldásokat a nemzetközi tapasztalatokkal veti össze. Empirikus anyagként tíz minisztériumi HR-vezetôvel lefolytatott mélyinterjúira támaszkodik. Gajduschek (2007) több kérdőíves adatfelvétel eredményeire támaszkodva elemzi a minősítésre és az ETÉ-re vonatkozó ún. tény-, illetve ezekre és a kompetenciaelemzés és -értékelésre vonatkozó véleményadatokat. Az ETÉ-re vonatkozó legmélyebb és legszisztematikusabb empirikus elemzést azonban Hajnal (2007) adta.

\section{Az ETÉ egy funkcionális modellje}

Hajnal egy ún. programmodellt állít fel, amely mintegy az ETÉ múködési mechanizmusát mutatja be az 1. ábrán szereplő logikai láncként. Hajnal aztán ezt a modellt „teszteli” négy kérdőívi kérdésre adott válaszok statisztikai elemzésével. A kérdések egy, a Magyar Közigazgatási Intézet által lebonyolított kérdő́ives adatfelvételből származnak. 
Hajnal az ETÉ programmodelljéról

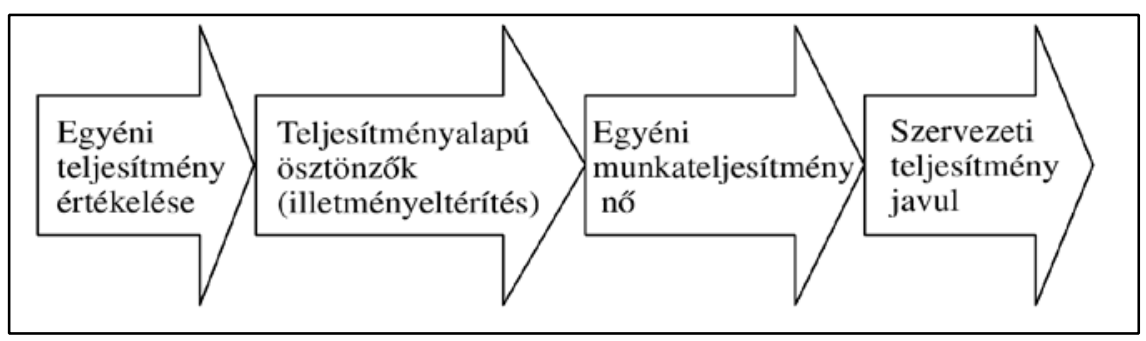

Az ETÉ egy bonyolultabb, „funkcionális” modellje

2. ábra
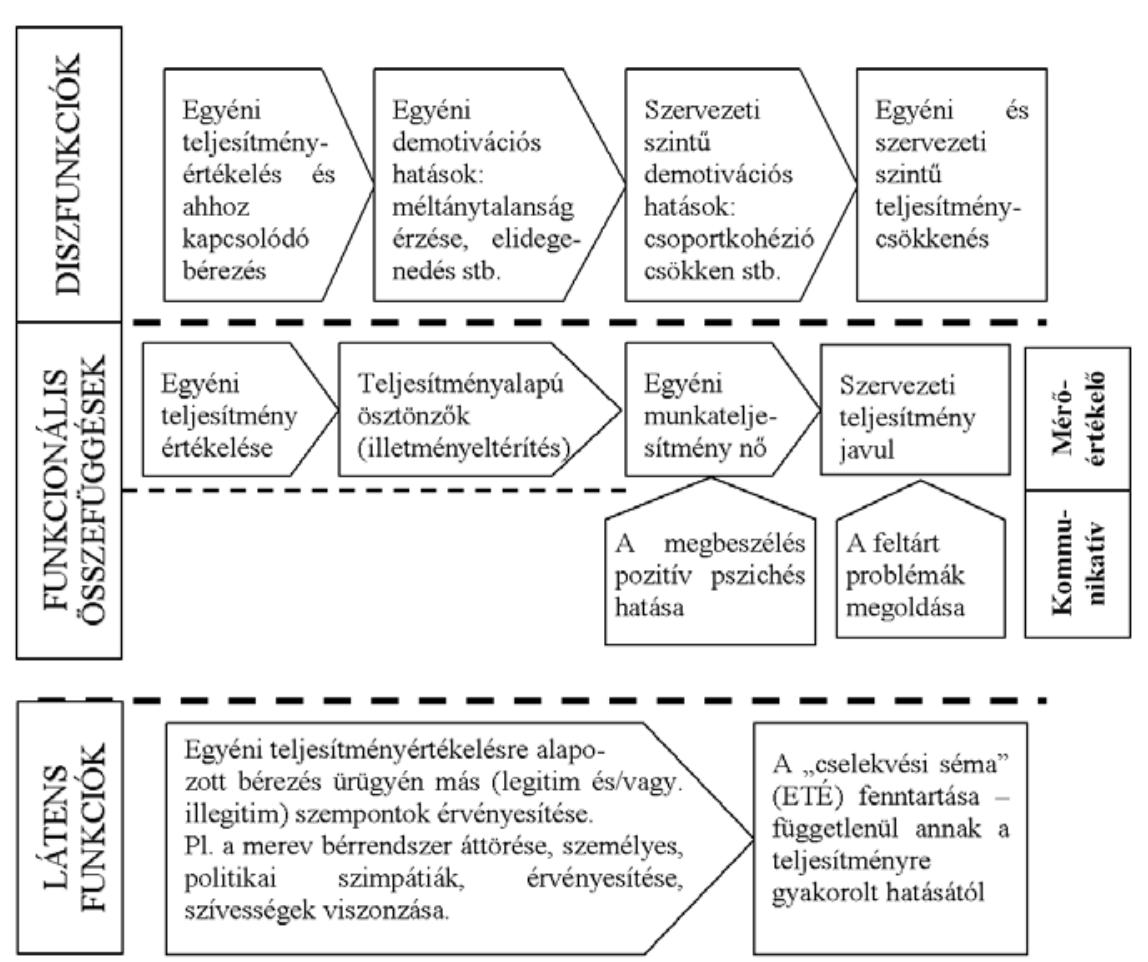

,a funkció”-t, illetve a „manifeszt funkciót" a társadalmi cselekvóknek a cselekvésük hatásáról alkotott explicit elvárásával azonosítja. A mertoni funkcionalizmus meghatározó gondolata az, hogy az így értelmezett „manifeszt funkció” mellett két további tényezôvel is számolni kell. Ezek: a „diszfunkciók” és a „látens funkciók”. Némi leegyszerúsítéssel élve, a „diszfunkciók” a cselekvés nem szándékolt, olykor a funkciótól gyökeresen eltéró, akár azzal ellentétes hatásaira utalnak. A „latens funkciók" pedig olyan hatások, amelyeket a cselekvốk nem tesznek explicitté (olykor a maguk számára sem, máskor csak a külvilág számára nem), ugyanakkor a látens funkció meghatározó szerepet játszhat a cselekvés, a cselekvési séma fenntartásában.

A fentieket figyelembe véve az ETÉ-vel kapcsolatban a 2. ábrán látható funkcionális modell állítható fel ${ }^{2}$.

A modell további finomítását jelenti, hogy az értékeló iskolák hatásmechanizmusában meglévő eltéréseket a modellben, azon belül a manifeszt funkciók körében is megjelenítettem. A két iskola jelenlétére és mibenlétére Hajnal maga is utal. Modelljében azonban csak a méróértékelő iskola hatásmechanizmusát vázolja fel, talán azért, mert a magyar rendszert ezzel azonosítja.

Jómagam az alábbi elemzésben Hajnal megközelítésétől két jelentôs pontban térek el. Elméleti oldalról, úgy vélem, hogy csak egy, a fentinél jóval komplexebb modellre alapozható az ETÉ hatásmechanizmusának értékelése. Módszertani szempontból pedig jóval több adatra támaszkodom: több kérdő́ives vizsgálat számos adatát felhasználom. Kétségtelen, hogy mindez csökkentheti az elemzés tiszta logikai zártságát, viszont úgy vélem, hogy az elemzés eredményeit jobban közelítheti a valós gyakorlat leírásához.

Az ETÉ vizsgálata során a - Robert K. Merton nevéhez köthető - funkcionalista megközelítést alkalmazom. Úgy vélem, hogy ez a megközelítés a jelen hazai közigazgatási gyakorlat leírására különösen alkalmas. Merton (1980: 143-256. old.), némileg leegyszerúsítve,
Kétségtelen súlyos érvek szólnak e felfogás mellett, de - pl. az intézményt bevezetố törvénymódosítás - indoklása arra utal, hogy a döntéshozók - alighanem alaptalanul bár, de - a kommunikatív iskola által ígért elónyökre is számítottak ${ }^{3}$.

A diszfunkciók és latens funkciók a manifeszt funkcióktól elkülönülten jelennek meg az ábrában. A diszfunkciók létezése, illetve annak lehetősége jól ismert az ETÉ nemzetközi és hazai szakirodalmában is; ezekre Hajnal (2007) maga is utal. A latens funkciók léte pedig elsôsorban a hazai gyakorlat ismerete alapján feltételezhetô. Utal erre pl. Linder (2006) is. Az pedig általánosan leírt tény (Shafritz et al., 1992: 67-93. old.; Owen, 2003: 149-164. old.; Lớrincz, 2006: 278-279. old.; Berényi, 1992: 25-46. old.), hogy az ún. zárt rend- 
szerú közszolgálat meglehetősen rugalmatlan rendszer, ahol a vezetők gyakran keresik a merevség áttörésének lehetôségeit. Ennek egyik módja a béreltérítés, amit akkor tekintünk latens funkciónak, ha tényleges oka nem a magasabb teljesítmény jutalmazása, hanem valamilyen más tényező.

\section{A felhasznált adatok forrásai}

Az alábbiakban, a szakirodalomban fellelhetô adatok mellett, a következő adatforrásokra támaszkodom:

1) A közigazgatásban az ún. HR-, illetve személyzeti feladatot ellátó vezetók, egyes esetekben HR-specialisták körében 2007 áprilisában végzett adatfelvétel. Ennek során 376 személyt kérdeztünk meg, akiket véletlen, rétegzett mintavétellel választottunk ki. A „HR-feladatot ellátók” meghatározása nem könnyü lecke. Lényegében három csoportot foglal magában. Ahol kifejezetten múködik HR szervezeti egység (a nagyobb közigazgatási szervekben), ott ennek vezetójét kérdeztük. Ahol a HR-feladatokat egy személy látja el teljes munkaidóben, vagy munkaideje egy részében, ott a kérdőívet ezzel a személlyel vettük fel. A többi esetben, tipikusan a kisebb közigazgatási szervekben, amelyek azonban az összes ilyen típusú intézmény jelentős hányadát teszik ki, annak elsố számú vezetôje válaszolt a kérdőívre. A kiválasztott szervek jól reprezentálják a közigazgatási szervek összességét. A továbbiakban erre az adatfelvételre mint a „HR-vezetók lekérdezése" fogok utalni.

2) Mintegy ezer fő, véletlen, rétegzett mintavételi eljárással kiválasztott köztisztviselő körében 2005 novemberében végzett adatfelvétel. A válaszadók jól reprezentálják a köztisztviselői kar egészét. A továbbiakban erre az adatfelvételre mint a ,köztisztviselók 2005-ös lekérdezése" fogok utalni.

3) Mintegy ezer fő, véletlen, rétegzett mintavételi eljárással kiválasztott köztisztviselő körében 2003-ban végzett adatfelvétel. A válaszadók jól reprezentálják a köztisztviselői kar egészét. A továbbiakban erre az adatfelvételre mint a ,köztisztviselók 2003-as lekérdezése" fogok utalni.

4) Ezerfős, véletlen mintavétellel kiválasztott aktív, szervezeti keretek között dolgozó népesség körében 2007 júliusában végzett kérdőíves adatfelvétel. Az adatfelvétel a munkahelyre, munkahelyi körülményekre vonatkozó kérdéseket tartalmaz, amelyek jórészt megegyeznek a köztisztviselóknek a fent említett kérdőívekben már feltett kérdésekkel. A továbbiakban erre az adatfelvételre mint ,,lakossági lekérdezésre" fogok utalni.
A kérdések tartalmaznak ún. „kemény”, „tény” és „puha”, véleményadatokat. Ezeket Hajnal (2007) külön elemezte. Jómagam a továbbiakban nem teszek ilyen határozott különbséget, részben azért, mert igyekszem az egy jelenségre vonatkozó információkat együttesen kezelni, részben mert - mint azt látni fogjuk, s mint arra Hajnal is utal - sok esetben a „tényadatok” tényszerúsége is meglehetősen kétséges. ${ }^{4}$

A dolgozat további részében előbb azokat az adatokat mutatom be, amelyek a köztisztviselóknek, valamint a HR-vezetốknek az ETÉ-vel és a béreltérítéssel kapcsolatos általános vélekedéseit tükrözik. Ezután a manifeszt funkciónak Hajnal (2007) által is elemzett vonalát tekintem át, részben Hajnal adatelemzésére támaszkodva, de további adatokat is bevonva az elemzésbe. Ezt követôen a manifeszt funkció másik lehetséges ,,vonalát”, nevezetesen a kommunikatív iskola által feltételezett hatásmechanizmust elemzem röviden. Végül külön részben tekintem át a diszfunkciók, valamint a latens funkciók esetleges jelenlétére utaló - szúkösen rendelkezésre álló, jórészt indirekt - információkat.

\section{Köztisztviselốk és HR-vezetốk általában az ETÉ-ról}

Nyilvánvalóan kevéssé beszélhetünk az ETÉ bármiféle hatásáról akkor, ha semmiféle ETÉ-re nem kerül sor. Hajnal (2007) bemutatja, hogy a köztisztviselők mintegy $14 \%$-a szerint esetükben egyáltalán nem került sor teljesítményértékelésre. A HR-vezetôk válaszai is hasonló tényekre utalnak. Eszerint a szervek $8 \%$-ában egyáltalán nem, további mintegy 6\%-ában pedig csak egyes köztisztviselókre végzik el a teljesítményértékelést.

További kérdés, hogy az ETÉ a valóságban követi-e a törvényben meghatározott eljárást, amelyre a manifeszt modell utal. Erról is megkérdeztük a HR-vezetóket. $^{5}$ A válaszadók $30 \%$-a jelezte, hogy a gyakorlat teljes egészében vagy jórészt eltér a jogszabályban megfogalmazott ideáltól, s csak $21 \%$ mondta azt, hogy teljes egészében megegyezik azzal. Noha az eltérés irányát nem ismerjük, erre kérdőívi kérdés nem vonatkozott, ez az adat a latens funkciók jelenlétére utalhat, de legalábbis arra, hogy a manifeszt funkció nem feltétlenül, illetve nem úgy érvényesül, ahogyan azt a KTV. alapján feltételeznénk.

Mind a HR-vezetốknek, mind a köztisztviselốknek tettünk fel olyan, ún. véleménykérdéseket is, amelyben általában kellett értékelniük az ETÉ-t és a hozzá kapcsolódó béreltérítést, illetve ezek együttes hatását. Az ezekre az általános kérdésekre adott válaszokat mutatom be az alábbiakban. 
A HR-vezetớket általánosságban arra kértük, hogy rangsoroljanak különféle tényezóket aszerint, hogy „azok milyen mértékben ösztönözik a köztisztviselóket jobb teljesítményre". Az átlagos rangsorszámok szerint növekvő sorrendbe szedve ${ }^{6}$ mutatom be a válaszokat az 1. táblázatban.

1. táblázat

Különféle tényezók

fontossági sorrendje, aszerint, hogy mennyire ösztönöznek jobb teljesítményre

\begin{tabular}{|l|c|c|}
\cline { 2 - 3 } \multicolumn{1}{l|}{} & $\begin{array}{c}\text { Átlagos } \\
\text { rangsorszám }\end{array}$ & Szórás \\
\hline Egyéb anyagi elismerés (pl. jutalom) & 3,32 & 1,92 \\
\hline Állásféltés & 3,83 & 2,46 \\
\hline Hivatástudat & 3,85 & 2,16 \\
\hline $\begin{array}{l}\text { Vezetó részéról megnyilvánuló } \\
\text { pozitív megítélés utáni vágy/negatív } \\
\text { megítéléstốl való félelem }\end{array}$ & 3,90 & 2,17 \\
\hline $\begin{array}{l}\text { Teljesítményértékelés, s a hozzá kötött } \\
\text { illetményeltérítés }\end{array}$ & 4,41 & 2,27 \\
\hline $\begin{array}{l}\text { Munkatársak részéról jelentkezó } \\
\text { megítélés szem előtt tartása - presztízs }\end{array}$ & 4,75 & 2,02 \\
\hline Előmenetel meggyorsítása & 5,18 & 2,05 \\
\hline $\begin{array}{l}\text { A KTV.-ben meghatározott cím } \\
\text { megszerzése }\end{array}$ & 6,19 & 1,86 \\
\hline
\end{tabular}

Az 1. táblázatból elsóként az túnik szembe, hogy a közigazgatás HR rendszerét szabályozó KTV-ben meghatározott eszközök (cím megszerzése, előmenetel meggyorsítása, ETÉ) a lista aljára kerültek, igaz, ezek között az ETÉ és a hozzá kapcsolódó béreltérítés viszonylag jó helyet foglal el. Ugyanakkor a legmeghatározóbb az anyagi elismerésnek egy másik, kevésbé szabályozott, esetlegesnek túnő formája. Miért lehet az „egyéb anyagi elismerés” jóval motiválóbb, mint a teljesítményértékelés? Logikailag két lehetséges válasz vetődik fel. Az egyik szerint az anyagi elismerés más formái jóval nagyobb összeget jelentenek, és ilyenként jóval motiválóbbak. A másik szerint ezek a juttatások jobban kötődnek a tényleges teljesítményhez, mint az ETÉ-re alapozott béreltérítés (mert pl. konkrét pluszfeladat elvégzéséhez kötődő „célprémiumról” van szó). Sajnos nem állnak rendelkezésre olyan adatok, amelyek alapján el lehetne dönteni, hogy melyik válasz, esetleg melyik milyen mértékben áll közelebb a valósághoz. Mindenesetre a táblázat adatai arra utalnak, hogy az ETÉ, amelynek elsődleges célja a motiváció, és ezen keresztül a teljesítmény fokozása lenne, e funkcióját - legalábbis a HR-feladatokat ellátók szerint - jelenleg kevéssé tölti be.

Természetesen rákérdeztünk konkrétabban is arra, hogy miként látják a HR-vezetók az ETÉ hatását. A következő kérdést tettük fel:
Hogyan ítéli meg, hogy pozitív hatással van-e a teljesítményértékelés és az esetleg hozzá kapcsolódó illetményeltérítés a köztisztviselók munkamoráljára - ösztönzi-e ốket a jobb teljesítményre?

1 - Igen, egyértelmúen ösztönző hatású.

2 - Az esetleges pozitív hatások mellett problémákat is felvet.

3 - Egyáltalán nem bír ösztönzố hatással. A válaszok megoszlását a 3 . ábra mutatja be.

3. ábra

Ösztönző-e a teljesítményértékelés rendszere?

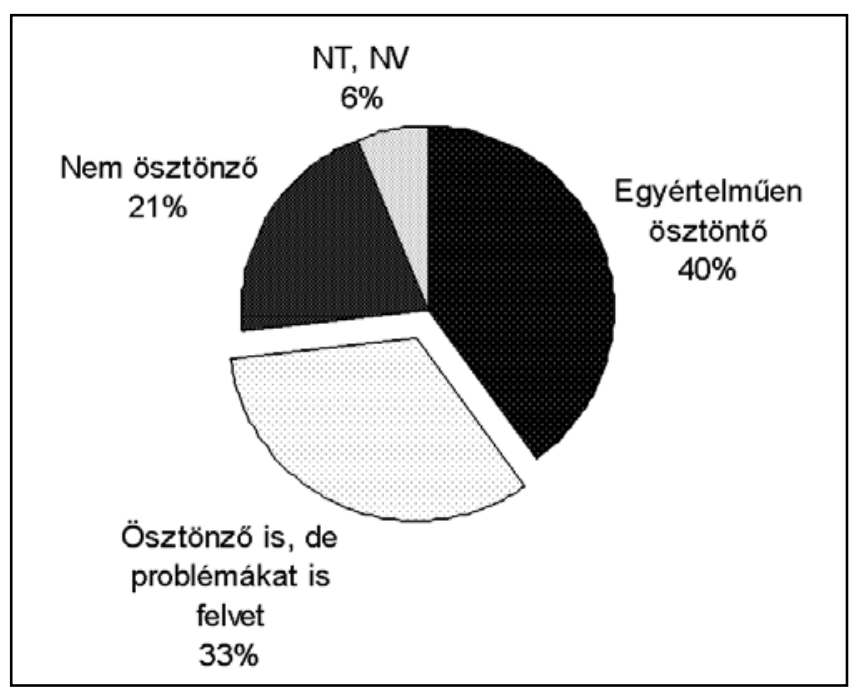

Azokat, akik a problémákra is utaltak, megkérdeztük arról is, hogy miben látják ezeket. A kérdésben a hazai és nemzetközi szakirodalomra alapozva fogalmaztuk meg a válaszalternatívákat. A válaszok így kapott megoszlását a 2. táblázat mutatja be.

A fontossági sorrendet - a pénztől eltekintve - azon tényezók vezetik, amelyek a teljesítmény objektív mérésének lehetetlenségére, illetve a szubjektivitás veszélyére utalnak. Ebben a tényben elsősorban az a diszkrepancia jelenhet meg, amely a magyar közigazgatás és közszolgálat sajátos jellege és a teljesítményértékelés rendje között fennáll, s amelyet szinte valamennyi hazai szerző hangsúlyoz (Hajnal, 2001; 2007; Linder, 2006; Karolinyné - Lévai, 2005). Ugyanakkor egy sajátos kultúra indikátora is lehet, amely a klaszszikus bürokratikus múködés, és az ahhoz kapcsolódó érdemrendszerú közszolgálathoz kötődik. (Berényi, 1992; Lórincz, 2005; Gajduschek, 2004). Erre utalhat a nemzetközi szakirodalomban széles körben tárgyalt, és gyakran az egyéni teljesítményértékeléssel szembeni pozitív alternatívaként bemutatott (Linder, 2006), csoport/team értékelés viszonylagos elutasítottsága is. A - weberi értelemben vett - bürokratikus múködésmódot a világosan meghatározott hatáskörök, a szabályok 
2. táblázat nem tudott a kérdésre választ

A teljesítményértékelés rendszerével kapcsolatban felmerüló esetleges problémák

\begin{tabular}{|l|c|c|}
\cline { 2 - 3 } \multicolumn{1}{l|}{} & \multicolumn{2}{c|}{ Említette } \\
\cline { 2 - 3 } \multicolumn{1}{l|}{} & HR-vezetók & $\begin{array}{c}\text { Akik } \\
\text { alkalmazzák } \\
\text { a béreltérítést }\end{array}$ \\
\hline $\begin{array}{l}\text { Kevés a költségvetési fedezet, így nem lehet megfelelóen } \\
\text { súlyozni a teljesítményeknek megfelelóen. }\end{array}$ & $83 \%$ & $87 \%$ \\
\hline $\begin{array}{l}\text { Nem lehet minden esetben objektíven értékelni, } \\
\text { és ez vezetói szubjektivitásra ad lehetőséget. }\end{array}$ & $63 \%$ & $64 \%$ \\
\hline $\begin{array}{l}\text { A közigazgatási munkában általában nem lehet értékelni } \\
\text { az egyéni teljesítményeket teljesítménymutatók alapján. }\end{array}$ & $52 \%$ & $52 \%$ \\
\hline $\begin{array}{l}\text { Nem megfelelóek a mutatók, amelyek alapján a } \\
\text { teljesítményt értékelik. }\end{array}$ & $38 \%$ & $34 \%$ \\
\hline $\begin{array}{l}\text { Rossz hangulatot, rivalizálást szül a köztisztviselók } \\
\text { között. }\end{array}$ & $36 \%$ & $41 \%$ \\
\hline $\begin{array}{l}\text { Jelenlegi formájában csak az alacsony illetmények } \\
\text { felzárkóztatására, forráskiegészítésre alkalmazzák. }\end{array}$ & $27 \%$ & $34 \%$ \\
\hline $\begin{array}{l}\text { Nem az egyének, hanem szervezeti egységek, teamek } \\
\text { teljesítményét kellene értékelni. }\end{array}$ & $19 \%$ & $17 \%$ \\
\hline Egyéb & $4 \%$ & $4 \%$ \\
\hline
\end{tabular}

adni. A köztisztviselók maguk tehát meglehetôsen megosztottak a kérdés megítélésében, bár egy picit többen vannak, akik nem látnak pozitív hatást.

Amikor azt kerestük - elsôsorban az ún. ANOVA módszerrel -, hogy statisztikai értelemben milyen tényezôk hatnak a véleményekre, nem meglepó módon azt találtuk, hogy messze a legszignifikánsabb szempont, hogy valakinek eltérítették-e a fizetését. Közel kétharmada azoknak, akiknek pozitív irányban eltérítették a fizetését, fogalmaz meg pozitív véleményt. A vezetók a beosztottakhoz képest jóval elutasítóbbak: 55\%-uk nem lát pozitív összefüggést,

és hierarchia uralma, s mindezzel együtt a szubjektivitás (így a vezetôii szubjektivitás) kiküszöbölésére való törekvés jellemzi. E jellemzók együttesen pedig a bizonytalanság minimalizálását szolgálják (Gajduschek, 2001). Nyilvánvaló, hogy a lényegében szubjektív vezetôi döntésen alapuló ETÉ és béreltérítés idegen ettôl a múködésmódtól és kultúrától.

A 2. táblázatban szereplő tényezók választása közötti összefüggés (ti., hogy az egyik választása valószínúbben vezet-e a másik választásához) elemzését is elvégeztük korrelációszámítás módszerével. Meglepő módon a statisztikai elemzés alig mutatott összefüggést az egyes szempontok választása között. Összesen csak két esetben (a „rossz hangulatot generál” és a „mérés objektivitásának hiánya”, valamint előbbi és a „teljesítménymutatók közigazgatási alkalmazásának lehetetlensége" között) találtunk egy százalék alatt szignifikáns korrelációt, míg egy ezrelék alattit egyáltalán nem. Így pl. a mutatók meg nem felelősége és a mérés objektivitásának hiánya között, meglepó módon, egyáltalán nincs korreláció. Nehéz lenne megmondani, hogy mi áll az összefüggések hiányának hátterében, de talán arról van szó, hogy a kérdezetteknek nincs egy jól strukturált képe az ETÉ-ról és annak hatásmechanizmusáról.

A köztisztviselôknek két, kifejezetten az ETÉ értékelésére vonatkozó egyszerú véleménykérdést tettünk fel a 2005-ös adatfelvétel során. Arra a kérdésre, hogy a teljesítményértékelés pozitív hatással van-e a munkamorálra, munkateljesítményre, a köztisztviselók 43\%-a válaszolt igennel és $47 \%$-a nemmel, míg további $10 \%$ míg ugyanez az arány a beosztottak esetében csak $46 \%$. Ha pedig eltekintünk azon vezetốk (29\%) véleményétől, akiknek illetményét pozitív irányban eltérítették, akkor a fenti arány $62 \%$-ra növekszik (de még az eltérítésben részesülók körében is $40 \%$-os ez az arány). Ez arra utal, hogy a vezetók meghatározó része, bár évek óta kötelességszerúen elvégzi e feladatot, a jogalkotó által annak tulajdonított pozitív hatásban, a gyakorlati tapasztalatok birtokában sem (vagy éppen azért nem) hisz. Érdekes, hogy a korral és közigazgatásban töltött idôvel nem sikerült semmilyen összefüggést találni. Ez cáfolni látszik azt a felfogást, hogy a nyugdíjhoz közelebb állók idegenkednének a teljesítményértékeléstől.

Ha a kérdés megítélését más véleményadatokkal vetjük össze, akkor azt érdemes kiemelni, hogy a közigazgatás átpolitizáltságának általános megítélése meghatározó szerepet játszik az ETÉ értékelésében. Azok, akik egyetértettek azzal a kijelentéssel, hogy a „közigazgatásban túl nagy a politika befolyása” a szakmai szempontokkal szemben, azok határozottan szignifikánsabban $(\mathrm{p}<0,001)$ nyilatkoznak negatívan az ETÉ-ról.

Egy következő kérdésünk kifejezetten a teljesítményhez igazodó díjazás elfogadottságát kívánta mérni. Az ilyen konkrét, húsbavágó kérdéseket általában megbízhatóbbnak tartjuk az általános kérdésnél. Igaz ugyanakkor, hogy a kérdés megfogalmazása olyan, hogy arra a béreltérítés megítélésén kívül számos más tényező is hathat. A kérdés pontosan a következóképpen hangzott: 
Mit tart fontosabbnak...

1. évente rendszeresen járó egyéb juttatások (pl. ruhapénz, 13. havi fizetés) megôrzését, bővítését, vagy

2. a kiemelkedố teljesítmények kiemelt díjazását.

A válaszadók $63 \%$-a választotta az elsố és $34 \%$-a a második válaszalternatívát. Látható tehát, hogy jóval kevesebben „szavaztak” az ETÉ-hez kapcsolódó béreltérítésre, mint az előzô, általánosabb kérdés kapcsán. Érdekes, hogy ebben az esetben a vezetóknek csak 42\%-a, míg a beosztottaknak $67 \%$-a ragaszkodott a status quót jelentô elsố válaszalternatívához. Az életkor elôrehaladtával a teljesítményhez igazodó bérezés (2. alternatíva) elfogadottsága egyértelmúen, bár nem jelentős mértékben csökken. Érdekes, hogy hasonló összefüggés a közigazgatásban töltött évek számával nem mutatható ki. Nem mutatható ki összefüggés a szervtípusok és a kérdésre adott válaszok között sem. A nagy és kis, az önkormányzati és az államigazgatási szervek dolgozói is összességében elutasítóak a teljesítménybérezéssel szemben. A közép- és felsőfokú végzettségúek összevetése pedig arra mutat rá, hogy míg a teljesítményértékeléshez kapcsolódó illetményeltérítést elóbbiek értékelték jóval pozitívabban, addig ebben a kérdésben a második válaszalternatívát inkább a felsőfokú végzettségúek választották.

A válaszokat statisztikai összefüggéseiben elemezve a legmeglepóbb mégis az, hogy az e kérdésre adott válaszok statisztikailag függetlenek az elóbb ismertetett kérdésre adott válaszoktól, vagyis az ETÉ általában való pozitív megítélésétôl. Ennek a ténynek több értelmezése is lehetséges. Így lehetséges, hogy bár a teljesítményhez igazodó bérezés növeli a teljesítményt, de a köztisztviselók nem akarnak teljesítménynövekedést. Lehetséges viszont az is, hogy valójában erôs kételyeik vannak a tekintetben, hogy a magasabb bér valóban tisztán a magasabb teljesítményhez fog-e kapcsolódni. Bár a rendelkezésre álló adatok alapján a kérdést nem lehet egyértelmúen eldönteni, további elemzés közelebb vihet a köztisztviselő́k megfontolásainak megértéséhez. Erre az alábbiakban még visszatérünk.

\section{Manifeszt funkció - hatás az ETÉ szerinti béren keresztül}

Hajnal által felvázolt logikai lánc teszteléséhez, a végéról visszafelé haladva, a következó kérdések tehetőek fel:

1) Az egyéni hogyan járul hozzá a szervezeti teljesítményhez?

2) A teljesítményalapú bérezés mennyire motivál?

3) A bér mennyire kötődik a teljesítmény értékeléséhez?

4) A teljesítmény értékelése mennyire reális?

\section{Ad 1) Hozzájárulás a szervezeti teljesítményhez}

E végsố kérdést nem vizsgáljuk. Egyfelól a kérdés vizsgálata kívül esik e tanulmány fókuszán (az ETÉ alkalmazása mint HR-feladat, illetve mint motivációs eszköz), másfelől nincsenek is a kérdés megválaszolását lehetôvé tévő adataink, hiszen annak vizsgálatára az általunk alkalmazott kérdőíves módszer teljesen alkalmatlan.

A továbbiakban elemzendő három kérdéssel kapcsolatban viszont érdemes utalni arra, hogy azok nagyban követik a motiváció Vroom (1964) ún. elvárás-elméletének logikáját. ${ }^{8}$

\section{Ad 2) Az ETÉ alapú béreltérítés hatása}

A Hajnal által felállított modellben a teljesítménynövelő hatás kizárólag a béreltérítésen keresztül érvényesül, és az dichotóm jellegú: növeli vagy nem növeli (értsd: változatlanul hagyja) az egyéni teljesítményt. Adataink szerint a köztisztviselók 18\%-ának térítették el a bérét (2005-ös adat), s ebból kevesebb, mint 1\%-ét (9 fơ) negatív irányban. Hajnal arra is rámutat, hogy az eltérítés mértéke viszonylag alacsony, az érintettek háromnegyede esetében nem több 10\%-nál. Utaltunk már arra is, hogy a HR-vezetốk a közigazgatási szervek 8\%-a esetén arról számoltak be, hogy egyáltalán nem végeznek ETÉ-t, és a szervek közel felében $(47,6 \%)$ az ETÉ-hez egyáltalán nem kapcsolódik az illetmény eltérítése. Igaz, ezek általában kisebb szervezetek, ahol a köztisztviselóknek is csak kisebb része dolgozik. Mindenesetre a béreltérítés hatása itt nem érvényesülhet.

Ezek az adatok arra utalnak, hogy a béreltérítésnek, már csak korlátozott hatóköre és mértéke miatt is, a közigazgatás egészére nézve viszonylag kis mértékú teljesítménynövelő hatása lehet. Ezt nagyban megerősíti az a már ismertetett adat is, hogy a HR-vezetók az ETÉ teljesítménynövelő hatását számos más tényezô mögé sorolták (1. táblázat).

\section{Ad 3) Mennyire kötôdik a bér az ETÉ eredményéhez}

Nyilvánvaló, hogy ha illetményeltérítésre egyáltalán nem kerül sor, s mint láttuk, sok esetben ez a helyzet, az azt is jelenti, hogy a kiemelkedő teljesítményt sem jutalmazzák, és az alulteljesítóket sem szankcionálják ilyen módon. A negatív eltérítés kis aránya is arra utal, hogy a béreltérítés és az ETÉ eredménye között csak meglehetôsen laza kapcsolat áll fenn.

Hasonló eredményre jutunk akkor is, ha azt vizsgáljuk, hogy kiknek térítették el nagyobb arányban a bérét. Ezt Hajnal alaposan elemzi, összesen 22 változónak az eltérítésre gyakorolt hatását tekinti át, és a legtöbb esetben nem talál összefüggést a béreltérítés ténye és olyan 
változók között, amelyekról azt feltételeznénk, hogy összefügg a teljesítménnyel. Így pl. nem talál összefüggést a közigazgatásban szerzett szakmai tapasztalattal, a felsőfokú képzettséggel (több diploma, tudományos fokozat stb.). A kérdésre még visszatérünk.

\section{Ad 4) Mennyire reális a teljesítmény értékelése}

A kérdés úgy is megfogalmazható, hogy a tényleges teljesítmény és az ETÉ eredménye mennyire függ össze? Nemzetközi tapasztalatok szerint ez az ETÉ egyik legproblematikusabb eleme, ami így a legtöbb diszfunkció forrása. (E kérdés mélyebb vizsgálatára tehát ott kerítünk sort.)

A 2005-ös kérdő́ivben kifejezetten rákérdeztünk arra, hogy „Véleménye szerint felettese mennyire reálisan értékeli munkáját?" Az óriási többség (86\%) szerint felettese mindig, vagy az esetek többségében reálisan értékeli munkáját. Ez, a nemzetközi tapasztalatok fényében, nehezen hihetô - ti., hogy a válaszadók valóban így gondolják. E ponton - egyetértve Hajnallal - arra kell utalnunk, hogy az e kérdésre adott válaszok nem tükrözik a válaszadók tényleges meggyőződését sokkal inkább a megszokott „pozitív gondolkodásukat", illetve aggodalmukat, hogy válaszaik esetleg a felettes kezébe jutnak. Az ilyen esetben egy jóval általánosabb, a vezetô szerepét nem nevesító kérdés informatívabb lehet. A 2005-ös vizsgálatban szerepelt egy ilyen kérdés. Az e kérdésre adott válaszok megoszlását

Az „Ön szerint a szakértelem, a tapasztalat és a megbízható, jó teljesítmény vagy

a személyes kapcsolatok határozzák meg, hogy ki kerül ma kiemelkedốen magas fizetéssel honorált közigazgatási állásba?"

kérdésre adott válaszok megoszlása

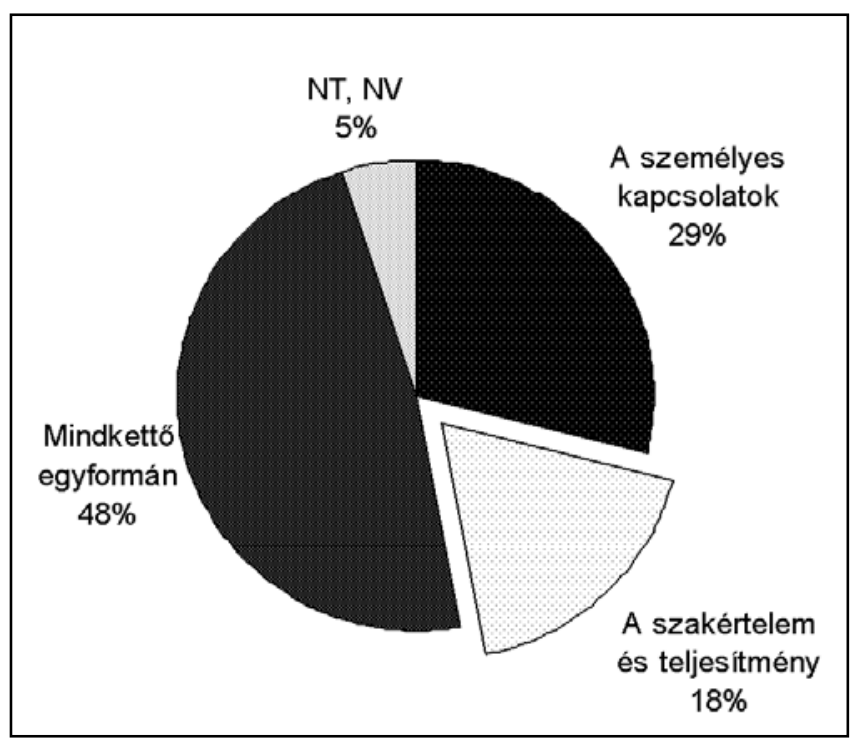

mutatja be a 4. ábra.

Látható, hogy az ilyen módon, általánosságban feltett kérdésre, amelyben a negatív válasz sem tünik éles, és fóleg nem személyre irányuló kritikának, a válaszadóknak már csak kevesebb mint ötöde állítja, hogy a magasabb bérek elsődlegesen a magasabb teljesítménynek tudhatóak be. Nyilvánvaló ugyanakkor, hogy ez a kérdés túl általános, egyáltalán nem csak az ETÉ alapú béreltérítésre vonatkozik. Nem lehet egyértelmúen eldönteni, hogy (a) ebben a kérdésben mertek a köztisztviselók ốszintén nyilatkozni, egyebek mellett az ETÉ-ról is, vagy (b) az, hogy míg más mechanizmusok (jutalmazás, előléptetés, címadományozás) alapvetôen személyes kapcsolaton alapulnak (s ezek határozzák meg a válaszok megoszlását), addig az ETÉ - ettől az általános tendenciától gyökeresen eltéróen - kifejezetten pontosan reflektál a valós teljesítményre és azt jutalmazza. Az (a) verziót támasztja alá az a tény, hogy az e kérdésre adott válaszok szorosan $(\mathrm{p}<0,001)$ korrelálnak az ETÉ általános megítélését firtató kérdéssel, valamint a legszorosabb korrelációt mutatja a „preferálja-e a teljesítménybérezést a status quóval szemben" kérdéssel (szorosabban összefügg, mint pl. azzal, hogy eltérítették-e a bérét). ${ }^{9}$

Egy hasonló tartalmú kérdést feltettünk már a 2003as kérdőívben is. 11 másik kijelentés mellett értékelni kellett azt az állítást is, hogy „Az elismerés és a jutalmak nálunk a tényleges érdemeken alapulnak", aszerint, hogy a kérdezett mennyire ért egyet azzal. Ugyanezt a kérést, hasonló kérdések társaságában feltették az Egyesült Államokban is, a már említett „Reinventing” adatfelvétel során. Miután megfelelố standardizálási eljárással kiküszöböltük azt a tényt, hogy a magyar köztisztviselők mindenre pozitívabb válaszokat adtak, azt találtuk, hogy a magyar válaszadók (a) ezzel a kijelentéssel - a 11-ból - a második legkisebb egyetértést mutatták, és (b) ebben a kérdésben relatíve jóval elégedetlenebbnek mutatkoztak az egyébként szintén elégedetlen amerikai kollégáiknál is. A relatív elégedettségi index a magyarok esetében $-0,39$, az amerikaiak esetében $-0,27$ volt. (A standardizált értékek -1 és +1 között mozognak.)

\section{Összegzés: manifeszt funkció, hatás a teljesítménybéren keresztül}

A rendelkezésre álló adatok arra utalnak, hogy számos szervezetnél az ETÉ-re egyáltalán nem kerül sor. Ahol arra sor kerül is, az esetek nagy részében nem pontosan a jogszabályi előírásoknak megfelelő módon történik az ETÉ. A bérek eltérítése a szervek mintegy felénél egyáltalán nem történik meg, s egészen kivételes az alulteljesítốknek ítéltek bérének csökkentése. Az ETÉ 
realitásával kapcsolatos köztisztviselói vélemények - a nemzetközi tapasztalatoktól eltéróen - meglepóen pozitívak voltak. E válaszok megbízhatóságával szemben azonban súlyos kételyek merülnek fel. Erre utalhat, hogy egy általánosabb, így kevéssé „,konfliktusos" kérdésre adott válaszok már kritikusabbak: a köztisztviselóknek komoly kételyeik vannak a tekintetben, hogy a magasabb fizetések a tényleges teljesítményhez kapcsolódnának, s ez a vélekedés határozottan kihat az ETÉ megítélésére is. Érdemes itt még visszautalni arra a tényre is, hogy a HR-vezetôk a teljesítményértékelés teljesítményösztönzô hatását más tényezókhöz viszonyítva meglehetôsen gyengének értékelték.

Egy másik, Hajnal által is alkalmazott, megközelítési lehetôség a tényadat jellegú változók és a béreltérítés ténye közötti összefüggések vizsgálata. ${ }^{10}$ Hajnal maga is jelzi, hogy az általa vizsgált 22 változó között, amelyek esetében pozitív összefüggést várt volna az ETÉ alapú béreltérítéssel, alig van olyan, amely ennek a várakozásnak megfelelt volna. Így pl. sem az iskolai végzettség szintje (ideértve a több diplomát, tudományos fokozatot), sem a nyelvtudás, sem a közszolgálatban szerzett tapasztalat nem mutat összefüggést a béreltérítéssel. Hajnal összesen három tényező́t talált, amelyek szorosan összefüggenek a béreltérítéssel: a beosztást (vezetô-nem vezetô), a szervtípust (ezek 4 típusát elkülönítve), és a tanfolyami részvételt (vett-e részt az utóbbi 3 évben közigazgatási képzésen). Mindhárom tényezô utalhat a jobb teljesítményre, de legalább ilyen mértékben más tényezôkre is. Különösen a vezetô beosztás, illetve a minisztériumi pozíció (amelyek nagyban predesztinálnak pozitív béreltérítésre) magyarázható a jobb érdekérvényesítô képességgel is. E kérdésre még visszatérünk. Itt csak azt szükséges ismét hangsúlyozni, hogy számos olyan tényezô, amelyról feltételezhetjük, hogy a teljesítménynek valamiféle proxy indikátora, semmiféle statisztikai összefüggést nem mutat az ETÉ alapján történő béreltérítéssel.

\section{Manifeszt funkció - az ETÉ „,béren kívüli’ hatása}

A manifeszt funkcióhoz soroltam az ETÉ mint kommunikatív aktusból folyó esetleges előnyöket is, amint az a 2. ábrán látható. Természetszerúleg nem rendelkezünk információval arról, hogy a feltárt problémákat milyen mértékben sikerült kiküszöbölni, s azok milyen mértékben vezettek aztán egyéni, illetve szervezeti szintú teljesítménynövekedéshez. Ezzel kapcsolatos adatok gyứjtésére a kérdő́ives módszer alkalmatlan.

Áttételes információval rendelkezünk viszont az ETÉ-hez kapcsolódó elbeszélgetés egyes, esetlegesen pozitív hatásairól. A 2003-as köztisztviselói lekérdezésben a fent említett 11 elemú kérdéssorban szerepelt egy olyan állítás is, hogy: „Pontosan tudom, mit várnak el tốlem a munkahelyemen.” E tekintetben a magyar köztisztviselók relatív egyetértési indexe jóval magasabb volt $(0,29)$, mint amerikai kollégáiké $(-0,27)$, akik ezen a területen mutatkoztak különösen elégedetlennek. Nyilvánvaló, hogy a kérdés meglehetôsen általános, és nem vonatkoztatható közvetlenül az ETÉ-re, de elképzelhetô egy olyan interpretáció, amely az ETÉ-nek jelentős szerepet tulajdonít e tekintetben. Ezzel az interpretációval csak az a baj, hogy az Egyesült Államokban mintegy három évtizede, 1978 óta (OECD, 2005: 30. old.; Shafritz et al., 1992: 489-507. old.) múködik az ETÉ. A fenti összehasonlító adatok tehát bizonyosan nem alkalmazhatóak az ETÉ pozitív hatása bizonyítékaként, egy ezzel ellentétes interpretáció azonban nem kizárt.

Több, a köztisztviselói kérdőívekben feltett kérdést a lakossági adatfelvétel során is lekérdeztünk. Ezek közül témánk szempontjából a következő kérdések túnnek relevánsnak:

- Tapasztalata szerint mennyire gyakran fordul elő az, hogy a beosztottak félnek kifejezni fónökükkel való egyet nem értésüket? (Válasz 1-5 terjedő skálán.)

- Egyetért-e a következő kijelentéssel: Közvetlen felettesem rendszeres és érdemi visszajelzést ad munkám erôs és gyenge oldalairól.

- Egyetért-e a következő kijelentéssel: Pontosan tudom mit várnak el tólem a munkahelyemen.

A lakossági kérdőív lehetôvé teszi az összehasonlítást. Elónye e lekérdezésnek, hogy az adatfelvételre az érintettek otthonában került sor, s, ellentétben a köztisztviselôi kérdőívekkel, nem a munkahelyen, ami - egyetértve Hajnal erre vonatkozó fejtegetésével - a köztisztviselốk „óvatos attitúdjének” egyik oka lehetett.

A lakossági kérdőívben a köz- és a magánszférában dolgozók csoportját különítettük el, és a két csoport válaszai közötti különbségeket vizsgáltuk az ANOVA módszerrel. ${ }^{11}$ Az ANOVA teszt eredménye nem mutatott szignifikáns eltérést a magánszféra és a közszféra dolgozóinak válaszai között a fenti három kérdés egyikében sem. Ez arra utal, hogy e területeken nem mutatkozik lényeges eltérés a köz- és a magánszféra viszonyai között. Annak fényében, hogy a közszférában dolgozók minden csoportja elvileg fokozott jogi védelmet élvez a „fónöki önkénnyel” szemben, különösen meglepó, hogy a fônöktôl való félelem a közszférában hasonló mértékben van jelen, mint a magánszférában. E tény önmagában is kétséget ébreszthet a tekintetben, hogy lehetséges-e vezetố és beosztott között ténylegesen ôszinte párbeszéd. 
A másik két kérdés pedig a teljesítményértékelés hatását kérdőjelezi meg. Ennek kapcsán azonban felvethetô, hogy

a) a magánszférában is alkalmazhatják, s esetenként alkalmazzák is az ETÉ valamilyen módszerét, és

b) a közszféra adatait a közalkalmazottak dominálják, akik jelentôs részénél az ETÉ nem kötelezô.

Ami az első felvetést illeti, a beosztásra vonatkozó, összesen 23 beosztotti csoportot nevesító kérdés alapján azt találtuk, hogy csak a teljes minta $29 \%$-a esetében (pl. irodai adminisztrátor, beosztott értelmiségi, középvezetô) túnik életszerúnek valamiféle ETÉ esetleges alkalmazása. Ezek jelentős része azonban a közszférában dolgozik. A második felvetést részben oly módon kezelhetjük, hogy a lakossági kérdoóívben kapott válaszok megoszlásait - figyelembe véve az ilyen összehasonlítás megbízhatóságát korlátozó számos tényezôt is - összevetjük az ugyanezen kérdésekre a korábbi köztisztviselói kérdőívekben adott válaszokkal. Nos azzal, hogy ,pontosan tudom, mit várnak el tólem...” lényegében azonos mértékben, durván 92\%-94\%, kaptunk egyetértő válaszokat a 2007-es lakossági és a 2003-as köztisztviselói adatfelvételben. A 2005-ös köztisztviselói adatfelvételben nagyobb - mintegy háromnegyedes - arányban kaptunk pozitív választ a „közvetlen felettesem rendszeres érdemi visszajelzést ad..." kijelentésre, mint a lakossági adatfelvételben, ahol ezzel mintegy kétharmadnyian értettek egyet. Az eltérés azonban alighanem abból adódik, hogy a kérdésben a közvetlen felettessel kapcsolatos esetleges kritika jelenhet meg, s ettôl a köztisztviselók, mint láttuk, különösen óvakodtak.

Összességében tehát az adatok nem látszanak bizonyítani azt, hogy a közigazgatásban alkalmazott ETÉ kommunikatív funkciója valóban érvényesülne, illetve bizonyos jelek egyértelmúen ennek ellenkezőjére utalnak.

\section{Diszfunkcióra utaló jelek}

A hazai (Karolinyné - Lévai, 2005; Hajnal, 2001; Linder, 2006) és fóleg a nemzetközi szakirodalomban nagy részt foglal el az ETÉ, különösen a mérő-értékelő változat negatív hatásainak tárgyalása. Shafritz et al. (1992: 489-507. old.) részletesen tárgyalja a különféle diszfunkciókat, amelyek között meghatározó probléma, hogy az érintettek nem érzik fairnek, méltányosnak az értékelést, az azon alapuló béreltérítés pedig feszültséghez, rivalizáláshoz vezet. Mindez elégedetlenséget szül, illetve akadályozza a szervezettel és a szervezeti célokkal való azonosulást; végsố soron határozott demotivációs hatása van.
A dán pénzügyminisztérium által 2001-ben publikált kutatás azt találta, hogy a dán köztisztviselók kezdetben üdvözölték a teljesítményhez igazodó bérezést, de már a bevezetés után nem sokkal sokan igazságtalannak tartották, és így az frusztrációhoz vezetett (Demmke, 2001: 169. old.), ami aligha járul hozzá a szervezeti hatékonyság növekedéséhez (lásd pl. Bakacsi, 1996: 107-109. old.).

Egy másik, az USA Georgia államában végzett 2001-es kutatás azt találta, hogy „csak az alkalmazottak 50\%-a mondta, hogy a teljesítményértékelés „fair” volt. $70 \%$ nem értett egyet azzal, hogy a teljesítményalapú bérezés alkalmas lenne a dolgozók motiválására, míg ez az arány a vezetók körében $75 \%$ volt. Ezenfelül $90 \%$ úgy vélte, hogy a teljesítményalapú bérezéshez nem áll rendelkezésre a szükséges pluszpénz [...]. A köztisztviselő́k több mint $90 \%$-a vélte úgy, hogy a kiemelkedôen jól teljesítók nem részesültek jelentôs fizetésnövekményben az új rendszerben”. (Demmke, 2001: 170. old.) Megdöbbentő, hogy bár teljesen eltérô a közigazgatási rendszer, más a kultúra, más a közszolgálat rendszere és hagyományai, az adatokból leszúrt eredmények mégis mennyire hasonlatosak a fentiekben bemutatott magyar adatokból levonható következtetésekhez.

Alighanem a méltánytalanságérzés és következményei kiküszöbölésére irányuló törekvés, valamint a konfliktuskerülés vezet aztán a teljesítményértékelések inflációjához: mindenki „kitűnően”, ,átlag felett” teljesít. Shafritz et al. (1992: 495. old.) egy 14.000 szövetségi köztisztviselôt érintô, 1989-ben lebonyolított adatfelvétel alapján pl. arról számol be, hogy bár a megkérdezett köztisztviselő́k hatvan százalékának értékelése a „teljesen kielégítơ” feletti (sic!) volt - felük mégis úgy érezte, hogy az értékelés nem volt fair.

A nemzetközi tapasztalatok fényében valami hasonlót várnánk a magyar közigazgatásban is. A méltánytalanság érzését erôsítheti maga a jogi szabályozás is. A törvény ugyanis lehetôvé teszi, hogy ugyanazon szerven belül, az ugyanúgy értékelt két személy közül az egyiknek eltérítsék, a másiknak pedig nem az illetményét - mindezt a vezetô szubjektív döntése alapján, indoklási kötelezettség nélkül (Gajduschek, 2004). Mindez már önmagában is méltánytalanságérzést generálhat.

A magyar kérdőívekből ugyanakkor kevés olyan adat áll rendelkezésünkre, amely a diszfunkciók meglétére utalna. Láttuk, hogy a konkrét kérdésre válaszolva a köztisztviselôk túlnyomó többsége fairnek mondta az értékelést, de láttuk azokat a tényeket is, amelyek ezzel kapcsolatban kételyeket ébresztettek. Összességében a köztisztviselók úgy látják, hogy a közszolgálatban a személyes kapcsolatok legalább 
annyira fontosak, vagy fontosabbak, mint a szakértelem és teljesítmény, és ez a vélekedés az ETÉ-vel kapcsolatos értékítéletükre is kihat.

A HR-vezetók alig több mint harmada jelezte, hogy az ETÉ feszültséget, rivalizálást eredményez. Szignifikánsan nagyobb arányban $(41 \%)$ jelezték viszont ezt azok, akik a béreltérítés rendszerét valóban múködtették. Ez azért figyelemre méltó, mert - értelemszerúen - azok, akik a béreltérítést nem alkalmazzák, általában inkább hajlamosak negatív hatásokat feltételezni, s az adatok is általában ezt támasztják alá. (Lásd 2. táblázat.) A feszültség, rivalizálás problémáját azonban éppen azok értékelik súlyosabbnak, akik alkalmazzák a béreltérítést, s így tapasztalatuk lehet annak hatásáról.

Az ETÉ-ek eredményeinek hiányában nincs tényadat, amely az ETÉ inflálódását bizonyíthatná. Egyes tényezók azonban arra utalnak, hogy ez a jelenség a magyar közszolgálatban is tetten érhetô. Ezt támasztja alá, hogy negatív irányú illetményeltérítésre egészen kivételesen az összes illetményeltérítésnek mintegy huszadában került sor. A minósítés, amely a köztisztviselő értékelésének másik formája, s amelynek eredményeirôl lehetett adatot gyưjiteni, hasonló tendenciát jelzett. A közigazgatási szervek 89\%-ában az utóbbi két évben egyáltalán nem született „,kevésbé alkalmas” és ,alkalmatlan” minôsítés. Összegezve, az értékelés inflálódására egyértelmú jelek utalnak.

Egyértelmú bizonyítékát a nemzetközi szakirodalomban jól ismert, és általában szinte elkerülhetetlennek tekintett más diszfunkciók jelenlétének a kérdőívekben nem találtuk. Ennek magyarázata alighanem a köztisztviselók már többször hivatkozott „,pozitív”, illetve „óvatos” attitúdjében keresendő. A diszfunkciók esetleges jelenlétének bizonyítására, illetve mértékének meghatározására a jelenlegi adminisztratív kultúra keretei között minden bizonnyal más módszerek alkalmasabbak, mint a kérdőíves adatfelvétel.

\section{Latens funkcióra utaló jelek}

A látens funkciót úgy értelmezzük, hogy az ETÉ, pontosabban az azon alapuló illetményeltérítés, nem a tényleges teljesítményre reflektál, nem a teljesítmény szintjét honorálja vagy szankcionálja, hanem a gyakorlatban más funkciót tölt be. ${ }^{12}$ Ennek lehetôségére több jel is utal. Ezek jó részéról más kontextusban már volt szó, ezért itt jobbára csak visszautalok ezekre:

- A köztisztviselóknek csak 43\%-a ért egyet azzal, hogy az ETÉ és a hozzá kapcsolódó béreltérítés valóban teljesítményösztöntő hatású. Az adatok mélyebb elemzése arra utal, hogy a köztisztviselók egy része úgy véli, hogy a magasabb bérek inkább személyes kapcsolatoknak, illetve - különösen az átpolitizáltabbnak tekinthetô minisztériumokban, nagy önkormányzatokban - a politikai lojalitásnak/szolgálatoknak tudhatóak be. (Lásd 8. lábjegyzet.)

- Különösen figyelemreméltó az az elemzés, amely az illetményeltérítésben részesülók és abban nem részesülók csoportjára vonatkozó „,kemény” adatokat veti össze. A vizsgált 22 változóból csak három mutatott szignifikáns összefüggést a teljesítményeltérítéssel. Ezután az egyébként nagyon óvatosan fogalmazó Hajnal is arra a következtetésre jut, hogy az ETÉre alapozott béreltérítéssel ,nem a kiváló munkateljesítményt, hanem egyéb, pillanatnyilag számunka ismeretlen egyéni jellemzóket jutalmaz”. A három tényezôboól ugyanakkor kettô esetében (vezetôk, minisztériumi dolgozók) legalább annyira plauzibilis a feltételezés, hogy a jobb érdekérvényesítő képességük miatt felülreprezentáltak a béreltérítettek csoportjában, mint az, hogy kiugró teljesítményük miatt kerültek volna ebbe a csoportba. ${ }^{13}$

- Hajnal elemzése csak arra vonatkozott, hogy eltérítették-e vagy sem valakinek a bérét. Ha külön elemezzük azt a csoportot, amelynek jelentősen $(10 \%$ felett) térítették el a bérét, akkor a Hajnal által feltárt tendenciák még erôteljesebben jelentkeznek.

- Emlékeztetünk rá, hogy a HR-vezetők az ETÉ-t és a hozzá kapcsolódó béreltérítést viszonylag hátra sorolták a teljesítményre ösztönző tényezôk között, pl. az esetenként adott jutalom mögé, ami legalábbis arra utal, hogy manifeszt funkcióját kevéssé tölti be.

- A HR-vezetók mintegy negyede értett egyet azzal a kijelentéssel, hogy ,jelenlegi formájában csak az alacsony illetmények felzárkóztatására, forráskiegészítésre alkalmazzák" az ETÉ alapú béreltérítést. Szignifikánsan nagyobb (Khi², szigif.<0,001) volt ez az arány azok körében, akik a béreltérítést alkalmazták, noha ennek épp a fordítottját várnánk.

- Végül ismét utalunk arra, hogy a törvény lehetôvé teszi/tette, hogy a vezető diszkrecionális döntése alapján két az ETÉ által egyébként azonos teljesítményứnek ítélt dolgozó közül az egyik számára - akár 40\%-os - béreltérítést alkalmazzon, míg a másik egyáltalán ne részesüljön béreltérítésben. Ez a disztinkció pedig, implicite, már magában a szabályozásban is arra utal, hogy a puszta teljesítményen túl a béreltérítést más tényezók is meghatározzák.

Összességében az adatok egyértelmúen arra mutatnak, hogy a teljesítményértékelés alapján történő béreltérítés nem, illetve nem csak a teljesítményre reflektál. 
Ehelyett a jobb érdekérvényesító pozícióban lévốk, a vezetôvel jobb személyes kapcsolatot kialakítók nagyobb valószínúséggel részesülnek ezen intézmény útján anyagi juttatásban. Egyes esetekben a béreltérítés a különleges szaktudásnak, illetve annak tudható be, hogy az adott szakember a munkaerópiacon a „normál” köztisztviselói bérért nem vásárolható meg. Az átpolitizáltabb szervezetekben felmerül a politikai lojalitás, illetve szolgálatok ilyen módon történô kompenzálásának gyanúja is. Nyilván számos olyan eset is van, amikor a béreltérítés valóban a kiemelkedô teljesítményre reflektál.

\section{Összegzés}

A fentiekben az ETÉ és az ahhoz kapcsolódó béreltérítés funkcionális elemzését kíséreltem meg elvégezni a rendelkezésre álló, több kérdőíves adatfelvétel során szerzett adatok alapján.

Az adatok összességében arra utalnak, hogy az ETÉ manifeszt funkcióját, nevezetesen a teljesítményösztönzést, motiválást az esetek egy jelentôs részében bizonyosan nem tölti be; ti. amikor egyáltalán nem, vagy nem a törvényi „,ideál”-nak megfelelóen alkalmazzák, illetve, amikor egyáltalán nem kapcsolódik hozzá béreltérítés. A véleménykérdésekre adott válaszok pedig azt jelzik, hogy az ETÉ teljesítménynövelő hatását általában a köztisztviselő́k, de még az érintettek (vezetôk, HR-vezetốk) is jelentôs mértékben megkérdôjelezik. A tényadatok elemzése e kételyt tovább erôsíti.

A manifeszt funkció érvényesülésének hiánya általában valamely latens funkció jelenlétére utal - hiszen ellenkezố esetben a cselekvési séma nem maradna fenn. Más a helyzet az ETÉ esetében, amelyet jogszabály ír elô, így akkor is múködtetni kellene, ha semmilyen funkciót nem töltene be. ${ }^{14}$ A „közvetett bizonyítékok” arra utalnak, hogy a gyakorlatban az ETÉ-t a zárt, érdemrendszerú közszolgálat merevségének áttörésére alkalmazzák, kihasználva azt, hogy lényegében diszkrecionális lehetôséget ad a vezetőnek, hogy egyesek bérét - a bértáblában meghatározottnál - magasabb szintre emelje. A béreltérítés oka lehet a kiemelkedó teljesítmény, de számos más tényező is. Ebben a helyzetben a béreltérítésre nyilván nagyobb esélyük van azoknak, akik ,közelebb ülnek a túzhöz”, a döntéshozatali központhoz.

A nemzetközi szakirodalomban általánosan tárgyalt témát jelentenek az ETÉ által okozott, szinte elkerülhetetlenül jelentkező diszfunkciók; mindenekelőtt a méltánytalanságérzés, a feszültség és rivalizálás, ami végső soron demotivációhoz vezet. Noha ezzel kapcsolatban direkt kérdést is feltettünk, a válaszok nem utaltak ilyesmire. Az adatok mélyebb elemzése azonban jelzi, hogy az ETÉ-re is vonatkoztatják a köztisztviselők azt a vélekedésüket, hogy a jól fizetett közigazgatási állások elnyeréséhez a személyes kapcsolatok legalább annyira fontosak, mint a teljesítmény. Ebben pedig a magyar köztisztviselók relatíve borúlátóbbak amerikai kollégáiknál is.

A manifeszt funkció érvényesülésével kapcsolatban adataink tehát kételyeket ébresztenek, a látens funkciók jelenlétét határozottan valószínúsítik, míg a diszfunkciók kapcsán éppen a más országokban általában megjelenố kritikus hangok szinte teljes hiánya elgondolkodtató.

$\mathrm{Az}$ a tény, hogy teljességgel egyértelmú értékelést sem a manifeszt, sem a latens, sem a diszfunkciók tekintetében nem tudunk adni, a további kutatás szükségességét jelzi. Ugyanez a tény azonban arra is felhívja a figyelmet, hogy a kérdőíves módszer alkalmazhatósága korlátozott, a jövớben más adatfelvételi technikák bevonására lesz szükség.

\section{Lábjegyzet}

2007. január 1-tól hatályba lépett a 301/2006. (XII. 23.) kormányrendelet, amely a teljesítményértékelés új rendszerét vezeti be, előbb csak a minisztériumi vezetókre, majd 2009-ig félévenként a köztisztviselók újabb csoportjaira kiterjesztve, a teljes központi közigazgatásra. Természetesen ez az elemzés még a korábbi teljesítményértékelési rendszerre vonatkozik, bár valószínúleg számos következtetése jól értelmezhetô az új rendszerre is. A bevezetés módját tekintve számos hasonlóság figyelhetô meg a korábbi rendszerrel. Így ennek során sem vették figyelembe a magyar közigazgatás sajátságait, ideértve a teljesítményértékelés során mostanra felhalmozódott tapasztalatokat is, s a nemzetközi gyakorlatra hivatkozás mögött sem áll tényleges kutatás. Noha a bevezetés fokozatos, az mégsem teszi lehetôvé a folyamatba épített korrekciót, s a teljesítményértékelést az összes beosztott köztisztviselőre is kiterjeszti. A bevezetést ezúttal sem előzte meg a szükséges tréning.

A rendszer egyébként rendkívül bonyolult. Amennyire azt a jogszabályból meg lehet érteni, az értékelés az érintett kiemelt, fejlesztési, valamint többletcéljait érinti. Ezen túl figyelembe veszi a munkaköri leírásban foglaltak teljesítését, valamint a kompetenciáknak való megfelelést. (5. § 5. bek.) Utóbbiakat a következô mintegy másfél év során a teljes államigazgatásra elkészítendő munkakörelemzések határoznák meg. A célok kitúzésére irányuló év eleji megbeszélésen túl az értékelés számos lépcsốből áll, beleértve a vezetối előértékelést, a köztisztviselő elôzetes tájékoztatását, az önértékelés szakaszát, majd az értékelő beszélgetést, illetve a végső értékelésről és az esetleges teljesítményjutalom mértékéról szóló tájékoztatást is. Mindennek során a vezetố az egyes értékeltekról évente egy mintegy háromszáz rubrikából álló, minimum 8 oldalas, ám a szöveges rész miatt tovább bôvítendő teljesítményértékelő lapot tölt ki. A teljesítményt a vezetố végül - 1-100-as skálán - összpontszámmal értékeli. Ám ennek a pontszámnak az adott szerven belül ún. ,eloszlási szintekre", lényegében sajátos állománycsoportokra tagolva (egy 
minisztériumban pl. 5 ilyen csoport van), meg kell felelnie annak az elvárásnak, hogy az adott állománycsoportnak csak meghatározott százaléka kaphat adott pontszámintervallumba eső pontot (pl. csak $10 \%$ kaphat $0-49$ pontot).

${ }^{2}$ Hajnal maga is utal az alábbi modellben foglalt számos elemre, sốt a diszfunkcionális hatásokat hangsúlyozza is, ugyanakkor ezeket nem foglalja be a modelljébe, így nem is elemzi szisztematikusan azokat.

3 A nemzetközi (OECD, 2005: 49-54. old.; Wise, 1996; Demmke, 2004: 110-117.old.) és a hazai (Karolinyné - Lévai, 2005; Bakacsi, 1996: 113-115. old.; Hajnal, 2001) szakirodalom egyaránt utal arra, hogy a teljesítményértékelés mint kommunikatív folyamat önmagában is számos pozitív hatáshoz vezethet. Így:

- világossá, egyértelmúvé teheti a beosztott számára a vele szemben megfogalmazott elvárásokat, illetve visszajelzést ad a vezető általi megítélésról,

- a vezetô számára információt biztosít arról, hogy a beosztott hogyan látja helyzetét, milyen nehézségekkel küzd, mi akadályozza a jobb teljesítmény elérésében,

- a fentiek mellett a megbeszélésnek önmagában is lehet motiváló, ösztönzố pszichés hatása, illetve alkalmas lehet a felgyülemlett feszülttség levezetésére, a konfliktusok explicitté tételére és kezelésére.

- A megbeszélés során feltárt objektív problémákat a vezető kezelni tudja, megteheti azokat az intézkedéseit, amelyek elhárítják a jó teljesítmény előtti akadályokat. (Pl. munkakörülmények javítása, megfelelő munkaeszközök biztosítása stb.)

${ }^{4}$ A szerzó immár mintegy másfél évtizede elemez köztisztviselő́k körében gyújtött survey adatokat. Ennek során néhány jól meghatározható sajátosságra figyelt fel. Ezek a sajátosságok különösen más országokban végzett köztisztviselői adatokkal összevetve szúrnak szemet. A legnyilvánvalóbb sajátosság, hogy a magyar köztisztviselő általában mindennel - de különösen közvetlen környezetével: vezetôjével, szervezetével - nagyon meg van elégedve. (Az „elégedettség” csak az anyagi és erkölcsi megbecsülésre vonatkozó kérdésekre nem áll.) A 2003-as adatfelvételben 11 olyan kérdést tettünk fel magyar köztisztviselőknek, amelyet 2000-ben az Egyesült Államok szövetségi köztisztviselóinek is feltettek (Reinventing government employee survey 2000. Washington, DC: Office of Personnel Management.) Lényegében valamennyi kérdésben jóval nagyobb volt a magyar, mint az amerikai „elégedettek” aránya. Mindeközben közismert, hogy a magyarok általában nem igazán ,pozitív gondolkodók”. Valóban, a köztisztviselők is meglehetôsen kritikusan, sốt keserúen tudnak nyilatkozni, ha már kialakult egy személyes, bizalmi kapcsolat a kérdezôvel. A kérdôívi válaszokat viszont úgy tûnik elkerülhetetlenül és növekvő mértékben a kincstári optimizmus uralja.

A másik jellegzetesség az ,igen, ehhez is értünk, ezt is csináljuk” típusú válaszadás. Így pl. egy 2003-as köztisztviselői adatfelvétel során a kérdezettek több mint háromnegyede állította, hogy tud táblázatkezelôt használni, bár a közigazgatásban forgolódók jól tudják, hogy ilyenre alig van példa. A HR-vezetók mintegy harmada jelezte, hogy alkalmazzák a kompetenciaelemzés és -értékelés módszerét, ám kontrollkérdésre kiderült, hogy a pozitív választ adók túlnyomó többsége nincs is tisztában azzal, mi ez a technika. Hasonlóképpen Hajnal György (2007/a) kutatásában olyan rendkívül bonyolult üzleti technikák, mint pl. a Business Process Reeingeneering alkalmazásáról számoltak be nagy arányban még kis közigazgatási hivatalok is, amelyek alkalmazása ezeknél egyszerúen kizárt.
A válaszokat elsődlegesen - szubjektív benyomásom szerint - mindig is, de egyre növekvő mértékben az egzisztenciális félelem, illetve a mindenáron való megfelelni akarás motiválja. Így a válaszok gyakran jobban reflektálnak arra, hogy a kérdezett mit gondol - sokszor tévesen - arról, hogy mi lehet a „helyes válasz”, az elvárás, mint a valóság tényeire. Ezt valamennyi válasz esetében figyelembe kell venni, és lehetôség szerint megfelelő eszközökkel kezelni.

5 A kérdés pontosan a következóképpen hangzott: „Ideális esetben a teljesítménycélok év eleji kitúzése a beosztott és a vezető közötti érdemi párbeszéd keretében születik meg. Ennek során figyelembe veszik a már elért eredményeket, objektívan igyekeznek meghatározni a kitûzendô célokat. Az egyéni teljesítménycélokat az ágazati, illetve szervezeti célokból vezetik le. Tapasztalata szerint a gyakorlat mennyiben tér el ettól az ideáltól?"

${ }^{6}$ Mivel rangsorolásról van szó, az alacsonyabb érték elóbbre sorolást, vagyis nagyobb fontosságot jelez.

${ }^{7}$ Az összes HR-vezető, aki jelezte, hogy a teljesítményértékelés problémákat is felvet.

8 Magyarul jó ismertetést ad: Bakacsi (1996: 104-107. old.). A teljesítményértékelés és az elmélet viszonyáról: OECD (2005: 32. old.).

9 A két kérdéssel kapcsolatos korrelációs adatokat mutatja be a következő táblázat:

\begin{tabular}{|l|c|c|}
\hline & \multicolumn{2}{|c|}{ Korrelációs együtthatók } \\
\cline { 2 - 3 } & $\begin{array}{c}\text { ETÉ növeli a } \\
\text { teljesítményt }\end{array}$ & $\begin{array}{c}\text { ETÉ alapú } \\
\text { béreltérítés } \\
\text { preferálása vs. } \\
\text { status quo }\end{array}$ \\
\hline Az ETÉ növeli a teljesítményt & $1,000 * *$ & 0,048 \\
\hline Eltérítették-e a bérét & $0,125 * *$ & 0,043 \\
\hline Felettese értékelése reális-e? & $0,159^{* *}$ & 0,009 \\
\hline $\begin{array}{l}\text { Magas fizetéshez teljesít- } \\
\text { mény v. kapcsolat kell? }\end{array}$ & $0,111 * *$ & $0,090 *$ \\
\hline $\begin{array}{l}\text { A politika nagy szerepet } \\
\text { játszik a közigazgatásban }\end{array}$ & $0,129 * *$ & 0,022 \\
\hline
\end{tabular}

* $\quad$ - szignifikancia $<=0,01$

$* *$ - szignifikancia $<=0,001$

${ }^{10}$ Ebben az esetben tehát együtt, egymástól el nem választva vizsgáljuk azt a kérdést, hogy az ETÉ mennyire reális (ad 4), és, hogy a béreltérítés mennyire alapszik az ETÉ-n (ad 3), vagyis: a béreltérítés mennyire kapcsolódik a tényleges teljesítményhez. Technikailag azért kell a béreltérítés tényéból kiindulni, mert magának az ETÉ-nek az eredményéról nincs információnk, illetve - az nem lévén standardizált - statisztikailag nehezen is lenne kezelhetô. A béreltérítés indikátora lehet a pozitív értékelésnek, hiszen arra kiemelkedő teljesítmény esetében kerül sor, bár ez az összefüggés fordítva nem áll fenn: a kiemelkedô teljesítmény, mint láttuk, nem feltétlen vezet pozitív béreltérítéshez.

${ }^{11}$ Az így kapott eredmények csak korlátozottan értelmezhetóek a köztisztviselôkkre, hiszen a közszférában számos más csoport is jelen van. Így a szolgálati jogviszony alá tartozók, akik esetében ETÉ-re szintén sor kerül, és a közalkalmazottak nagyobb csoportja, akik esetében a közalkalmazotti törvény maga nem teszi kötelezővé az ETÉ-t.

${ }^{12}$ Utaltam már rá, máshol pedig részletesen is kifejtettem (Gajduschek, 2004), hogy az olyan intézményeknek, mint az 
ETÉ, egyszerúen létezésük miatt van egy erôteljes szimbolikus funkciója. Jelen esetben a „modern”, ,üzleti stílusú”, a „,nemzetközi trendeket közvetlenül követő”, ,,hatékony”, ,,nem bürokratikus" közigazgatás képét sugallja. Ez a fajta latens funkció azonban magának az intézménynek a meghirdetésével, Magyarországon: jogszabályba foglalásával érvényesül. Az alábbiakban az ETÉ-nek a gyakorlatban megjelenő esetleges latens funkcióit kutatjuk

${ }^{13}$ Ez utóbbi feltételezés megalapozott lehetne, ha a karriertervezés, az elómeneteli rendszer erre alapot adna. Ha pl. a minisztériumi apparátusok jórészt az alsóbb szintú szervekból a legkiválóbbakat kiválogatva állnának fel, vagy a vezetôk szigorú kiválasztási eljárásban, megfelelő feltételek megléte esetén kerülhetnének pozícióba. Erról azonban - mint azt máshol bemutattam (Gajduschek, 2004; 2005) - a magyar közigazgatásban nincs szó.

${ }^{14}$ Pontosan ez a helyzet a minősítéssel, amelynek a mai közszolgálati rendszerben kizárólag szimbolikus funkciója van.

\section{Felhasznált irodalom}

Bakacsi Gy. (1996): Szervezeti magatartás és vezetés. Budapest: KJK

Bossaert, D. - Demmke C. (2003): Civil Services in the Accession States. Maastricht: EIPA

Crozier, M. (1981): A bürokrácia jelensége. Budapest: KJK

Demmke, C. (2004): European Civil Services between Tradition and Reform. Maastricht: EIPA

Gajduschek Gy. (2001): Bureaucracy: Is it Efficient? Is it Not? Is that the Question? Administration and Society Vol, 34 No. 6

Gajduschek Gy. (2004): A magyar közszolgálati szabályozás egyes sajátságai. In: Állam- és Jogtudomány XLV. 3-4.

Gajduschek Gy. (2005): Szakértelem és/vagy politika. A magyar közszolgálat jogi és empirikus elemzése. Politikatudományi Szemle 2005/2 pp. 111-134.

Gajduschek Gy. (2007): A köztisztviselő munkájának értékelése. A magyar jogi szabályozás és gyakorlat elemzése az empirikus adatok tükrében. Humánpolitikai Szemle (megjelenés alatt)

Hajnal Gy. (2001): Egyéni teljesítménymérés és -értékelés a közigazgatásban: tapasztalatok és lehetôségek a magyar KTV-szabályozás tükrében (Kézirat, Magyar Közigazgatási Intézet)

Hajnal Gy. (2007): Az egyéni teljesítményértékelési rendszer múködésének tapasztalatai a magyar közigazgatásban. Vezetéstudomány 2007, 7-8. sz.

Hajnal Gy. (2007/a): Az önkormányzati hivatali múködés korszerúsítésének irányai és lehetőségei. Vezetéstudomány 2007, 10. sz.

Habermas J. (1981): A kommunikatív cselekvés elmélete. Budapest: ELTE Szociológiai Intézet

Haque, Shamsul M. (2006): Modernizing Government: The Way Forward - An Analysis. International Review of Administrative Sciences 2006/3.
Ingraham, P. W. (1996): Evolving Public Service Systems. In: Perry, James L. (ed.): Handbook of Public Administration. San Francisco: Jossey-Bass pp. 375-395.

Karoliny M. - Lévai Z. (2005): Teljesítményértékelés a közszolgálatban. In Karoliny Mártonné - Lévai Zoltán - Poor József: Emberi eróforrás-menedzsment a közszolgálatban. Budapest: Szókratész.

Kettl, Donald F. (2006): Modernizing Government: The Way Forward - A Comment In: International Review of Administrative Sciences 2006/3.

Linder V. (2006): Az egyéni teljesítményértékelés és kompetenciaalapú emberi eróforrás-gazdálkodás a közszolgálatban. In: Humánpolitikai Szemle XVII/10. pp. 30-45. és XVII/11 pp. 48-55.

Lórincz L. (2005): A közigazgatás személyi állománya. In: Lőrincz Lajos: A közigazgatás alapintézményei. Budapest: HVGORAC pp. 259-405.

Merton Robert K. (1980): Társadalomelmélet és társadalmi struktúra. Budapest: Gondolat

Meyer-Sahling, Jan-Hinrik (2006): The Institutionalization of Political Discretion in Post-communist Civil Service Systems. The Case of Hungary. In. Public Administration Vol 84, No. 3, pp. 693-716.

OECD (2005): Performance-related Pay Policies for Government Employees. Paris: OECD Publishing

OECD (2005/a) Modernising Government. Paris: OECD GOV/PGC/RD (2005/2.)

OECD (2004): Trends in Human Resources Management Policies in OECD Countries. An Analysis of the Results of the OECD Survey on Strategic Human Resources Management. GOV/PGC/HRM 2004. 3FINAL

OECD (2003): Public Sector Modernisation. Modernising Public Employment. Paris: OECD 2003 GOV/ PUMA(2003)18, 28 Oct. 2003

Owen, E.H. (2003). Public Management and Administration, New York: Palgrave Macmillan

Shafritz, J.M. - Riccucci, N.M - Rosenbloom, D.H - Hyde, A.C. (1992): Personnel Management in Government. New York: Marcel Dekker

Talbot, Colin (2006): Modernizing Government: The Way Forward - A Comment. In: International Review of Administrative Sciences 2006/3.

Wilson, James Q. (1989): Bureaucracy. What Government Agencies Do and Why They Do It? US: BasicBooks

Wise, Lois R. (1996): Enhancing Employee Performance. In: In: Perry, James L. (ed.): Handbook of Public Administration. San Francisco: Jossey-Bass pp. 392-404.

Wroom, V.H (1964): Work and Motivation. New Yourk: John Wiley \& Sons

Cikk beérkezett: 2007. 6. hó

Lektori vélemény alapján átdolgozva: 2007. 9. hó 